\title{
Adaptation to climate change in the Mekong River Basin: introduction to the special issue
}

\author{
Jaap Evers ${ }^{1} \cdot$ Assela Pathirana ${ }^{1}$
}

Received: 13 February 2018 / Accepted: 15 June 2018 / Published online: 3 July 2018

(C) Springer Nature B.V. 2018

\section{Introduction}

Adaptation, the adjustment in natural or human systems to a new or changing environment (Smit et al. 2000; Watson and Albritton 2001), has come to the forefront of discussions on climate change. Over the past decade, the number of scientific publications on adaptation to climate change has quadrupled (see Fig. 1). Human adaptation to climate change is about changing and adjusting behaviors at the present and also developing strategies to deal with the impacts of expected climate change in the near and far future. The majority of the world's governments have ratified or signed the Paris Climate Agreement which, in addition to aiming to keep global warming below $2{ }^{\circ} \mathrm{C}$ above pre-industrial levels and to pursue efforts to limit the temperature increase to $1.5{ }^{\circ} \mathrm{C}$ above pre-industrial levels, established a global goal of "enhancing adaptive capacity, strengthening resilience and reducing vulnerability to climate change" (Article 7). Yet, investment in adaptation is to date insufficient; the annual costs of adaptation for developing countries have been estimated as between US\$140 billion and US $\$ 300$ billion by 2030, an order of magnitude greater than current financing (UNEP 2016). Greater communication, cooperation, and coordination of both policy and scientific work that crosses both disciplinary and geographical boundaries are needed to help reduce or clarify uncertainties in future climate projections and inform adaptation decisions.

This special issue attempts to improve the knowledge related to climate change adaptation in the Mekong River Basin and contribute to the broader literature on climate change adaptation (Fig. 2). The focus on the Mekong River Basin is critical: past research on climate change adaptation in the basin is limited, key areas in the basin have been identified as vulnerable to climate change (e.g., the Vietnamese Mekong Delta, the Cambodian Tonle Sap lake), and the basin is developing rapidly.

Jaap Evers

j.evers@un-ihe.org

1 IHE Delft - Institute for Water Education, Delft, The Netherlands 


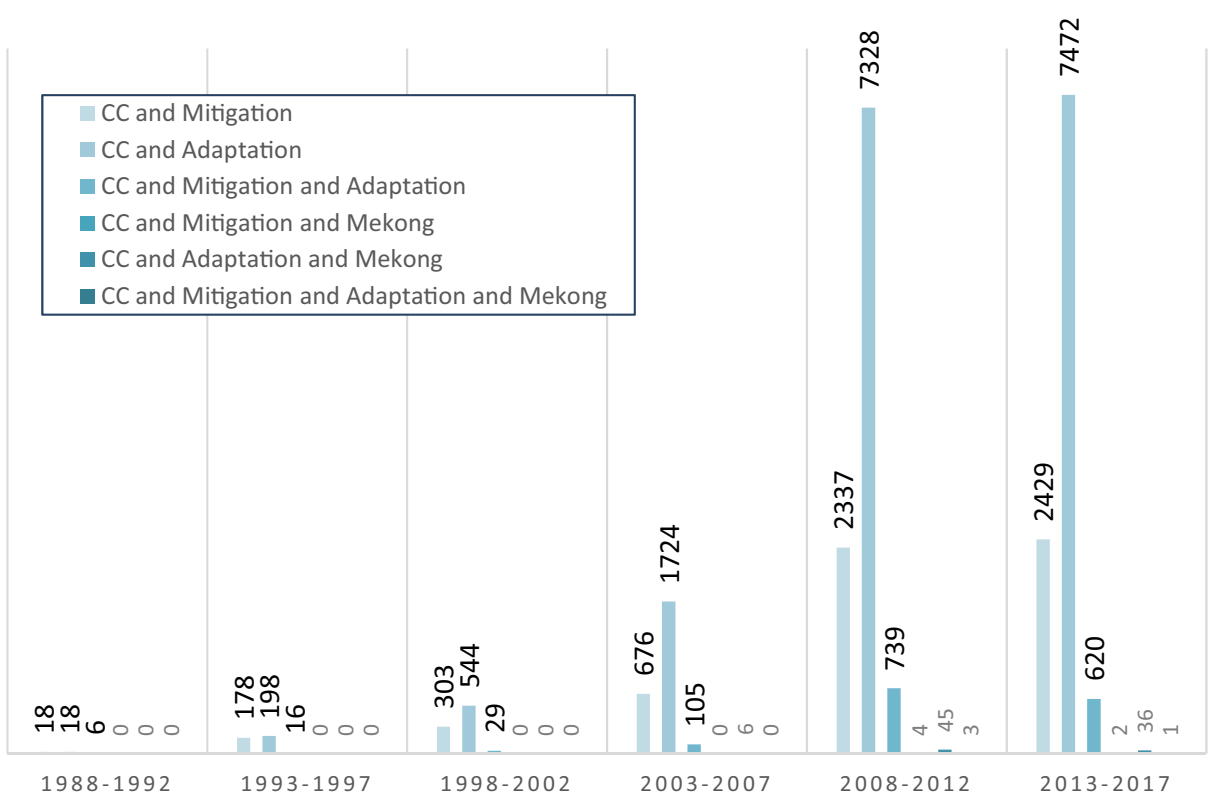

Based on Google Scholar search "allintitle: climate change mitigation adaptation", "allintitle: climate change mitigation ", "allintitle: climate change adaptation", similar search phrases were used including "Mekong", searches where done for the respective time periods.

Note: the search results unavoidably do contain titles of papers wich are not relevant for the topic under discussion.

Fig. 1 Number of search results in Google Scholar with climate change and mitigation and/or adaptation with/ without Mekong in title, 1988-2017

This special issue will contribute to developing sustainable climate change adaptation strategies at basin, national, regional, and local scales.

The papers in this issue focus on four interrelated themes: (1) impacts of climate change and human interferences on water, nutrient, and sediment flows (Shrestha et al. 2018); (2) climate change adaptation in urban centers (Radhakrishnan et al. 2018; Pathirana, Radhakrishnan, Ashley, Nguyen, and Zevenbergen 2018; Pathirana, Radhakrishnan, Nguyen, and Zevenbergen 2018); (3) climate change adaptation in rural areas (Gong et al. 2018; Gustafson et al. 2018); and (4) transboundary river management (Ngo et al. 2018).

In the following section, we discuss the impacts of climate change on water resources in the Mekong River Basin. Next, we continue to further discuss the relation between climate change impacts and other developments in the basin and the interrelations. Finally, we present the lessons learned from the various contributions to this special issue and provide some overall conclusions.

\section{The Mekong River Basin water resources and climate change}

The Mekong is a transboundary river with its watershed spanning over PR China, Myanmar, Thailand, Lao PDR, Cambodia, and Vietnam (Fig. 2). The portion of the 


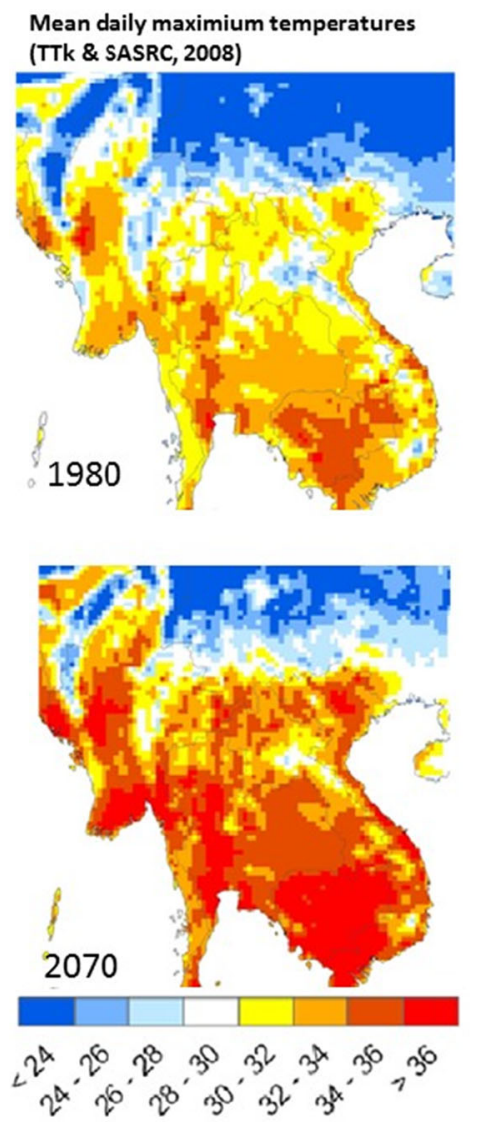

Change in mean annual precipitation, comparing means 1985 2000 and 2026-2041 (MRC, 2010b)

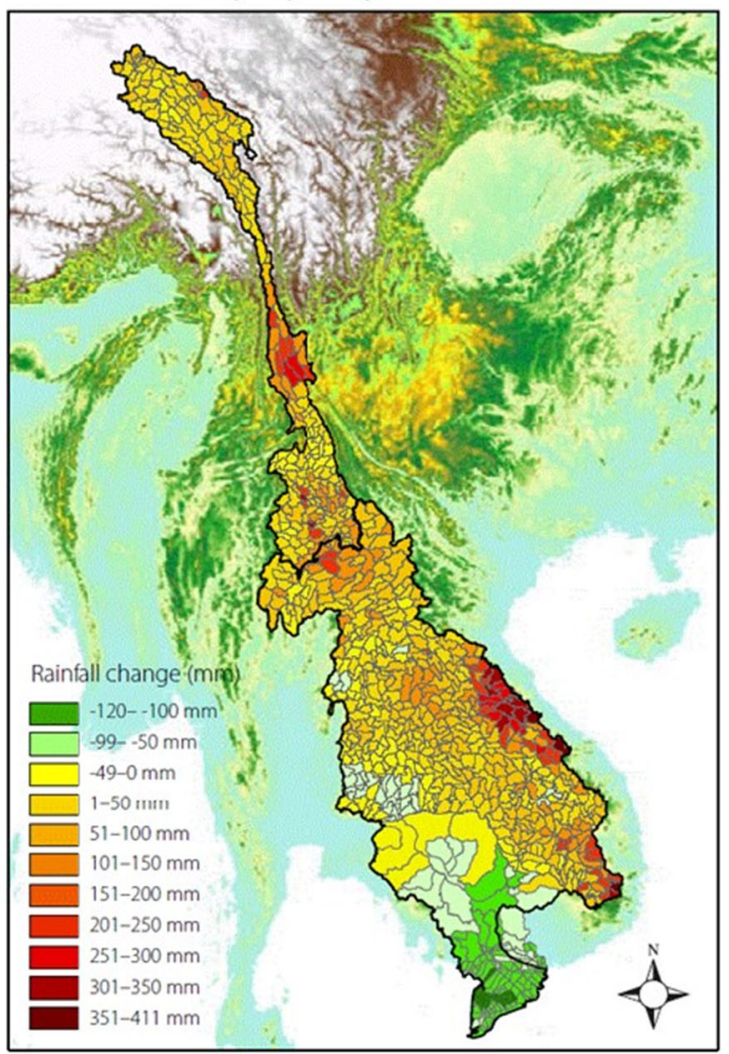

Fig. 2 Forecasted mean annual maximum daily temperature change (left; source: TTK and SASRC 2008) and forecasted mean annual precipitation change (right; source: MRC 2010)

watershed in the latter four countries is also referred to as the Lower Mekong River Basin. ${ }^{1}$ The water resources of the Mekong River Basin are less well understood and less developed compared to the other large river basins of the world (e.g., Danube, Nile, and Amazon). Several emerging issues affect water security in the Mekong River Basin and its inhabitants' ability to adapt to climate change. First, by 2060 , the total population in the basin is projected to reach approximately 83 million, an increase of approximately $20 \%$ (MRC 2016). Though much of the population will live in urban environments, ${ }^{2} \mathrm{a}$ large fraction of the population is expected to remain strongly dependent on the water resources of the Mekong River Basin for irrigated agriculture and fisheries. Second, there are plans for expansion of irrigation schemes and many hydropower projects (MRC 2016). Hydropower development, in tributaries and the main stem, results in unequal distribution of costs and benefits (Merme et al. 2013). Third, urbanization and economic

\footnotetext{
${ }^{1}$ Cambodia, Lao, Thailand, and Vietnam are council members of the Mekong River Commission. Myanmar and China are dialogue partners.

${ }^{2}$ The MRC (2016) expects that by 2060, between 50 and $70 \%$ of the people in Thailand, Vietnam, and Lao PDR, and $35 \%$ in Cambodia are living in cities.
} 
development are causing declining water quality and increasing irrigation demand. Reduced water and sediment flows contribute to coastal erosion, soil subsidence, and saltwater intrusion in the Vietnamese Mekong Delta (MRC 2016).

In addition, the Mekong River Basin is also undergoing rapid socioeconomic change. A growing population and increasing wealth creates greater demand for water, energy, and food and drives land cover change. The challenges of managing and allocating water resources are exacerbated by the continuous development of dams in the Mekong River Basin. Water resources management and broader societal challenges might be amplified by the interaction of climate change and human interventions in the river basin and its local subsystems (e.g., hydropower dams, urban centers, irrigation systems).

Given these challenges, the projected impacts of climate change (changing rainfall patterns, sea level rise, droughts, and temperature changes) in the Mekong River Basin are of major concern for the riparian countries and its people. Climate change can have a significant impact on river flow patterns, flood frequency, river and coastal ecology, and the services the river provides to the population (Table 1).

Existing studies about future climate impacts in the Mekong Basin broadly share a set of common themes: increased temperature and annual precipitation, increased flood depths and duration in the Mekong Delta and Cambodian floodplain, variability in runoff, prolonged agricultural droughts in the south and the east of the basin, and sea level rise and salinity intrusion in the Mekong Delta (Eastham et al. 2008; MRC 2009, 2010; Murphy, Irvine, and Sampson 2013). For example, compared to the period 19852000, the Mekong River Commission forecasts the following likely changes of climate for the period 2026-2041 (MRC 2010) $)^{3}$ :

- A basin wide average temperature increase of $0.79^{\circ} \mathrm{C}$ (ranges from 0.68 to $0.81{ }^{\circ} \mathrm{C}$ ), with greater increases for colder catchments to the north,

- An average annual precipitation increase of $200 \mathrm{~mm}$ (equivalent to $+13.5 \%$ ) predominantly from increased wet season precipitation,

- An increase in dry season precipitation in northern catchments and a decrease in dry season precipitation in southern catchments,

Table 1 Basic data on country share of Mekong Basin territory and water flows (MRC 2005)

\begin{tabular}{|c|c|c|c|c|c|c|c|}
\hline & $\begin{array}{l}\text { PR } \\
\text { China }\end{array}$ & Myanmar & $\begin{array}{l}\text { Lao } \\
\text { PDR }\end{array}$ & Thailand & Cambodia & Vietnam & Total \\
\hline Area in basin $\left(\mathrm{km}^{2}\right)$ & 165,000 & 24,000 & 202,000 & 184,000 & 155,000 & 65,000 & 795,000 \\
\hline $\begin{array}{l}\text { Catchment as percentage of Mekong } \\
\text { River Basin }\end{array}$ & 21 & 3 & 25 & 23 & 20 & 8 & 100 \\
\hline $\begin{array}{l}\text { Contribution to the flow as } \\
\text { percentage of Mekong River } \\
\text { Basin }\end{array}$ & 16 & 2 & 35 & 18 & 18 & 11 & 100 \\
\hline
\end{tabular}

\footnotetext{
${ }^{3}$ The data is based on projections and simulations of the International Centre for Environmental Management (ICEM, 2009) for the MRC using the general circulation models (GCM) and using the scenarios of the Intergovernmental Panel on Climate Change (IPCC).
} 
- An increase in annual basin flow of $21 \%$ which will mostly occur during the wet season and will maintain or improve water availability in the catchments. However, pockets of high levels of water stress are expected during the dry season in northeast Thailand and Tonle Sap Lake in Cambodia,

- An increase in flooding in all parts of the basin, including more frequent flash floods in mountainous upstream catchments and increased flood extent downstream along the main stem of the Mekong River.

\section{Climate change and development in the Mekong River Basin}

Although the Mekong River Basins is, from a water resources perspective, underdeveloped, the situation is very dynamic. The riparian countries are undergoing rapid socioeconomic development. The associated changes in land use, livelihoods, and wealth distribution are having great impact on land and water use, and also increasing vulnerability to climate change. This socioeconomic development, including the infrastructure interventions that invariably follow, in combination with climate change creates both vulnerabilities and opportunities for the people. In this section, we present findings from the literature on interactions between climate change, socioeconomic development, and human interventions in the Mekong River Basin.

Intensified floods and droughts have dramatically impacted agriculture and fisheries in some areas of the basin. For example, Brooks and Adger (2003) found that climate impacts account for almost $90 \%$ of rice production losses in Cambodia during the 19962001 periods. Climate change and the development of hydropower dams increase the vulnerability of communities relying on fisheries for income and nutrition in Cambodia and Vietnam (Allison et al. 2009; Halls 2009; Hijioka et al. 2014).

Climate impacts and lack of resilience contributes to a further urbanization of people moving out of agriculture and into the city. Floods are playing an important role in migration in the Mekong Delta (Warner 2010). Vietnamese peri-urban farmers in the Mekong Delta are facing multiple burdens due to socioeconomic transformations, like land entitlement insecurity, local bio-physical degradation, and climate change impacts, as they do not benefit from the (inner) urban disaster risk management measures. At the same time, these peri-urban farmers are also profiting from higher market demands from the urban areas (Garschagen et al. 2011). The impacts of past floods in the Vietnamese Mekong Delta expose the rural population's lack of access to alternative livelihoods and difficulty in maintaining existing livelihoods. Household debts contribute to the pressure to migrate to urban areas (Dun 2011). Similarly, in and around the Tonle Sap Lake in Cambodia, the impacts of repeated floods have contributed to migration (Nuorteva et al. 2010; Keskinen et al. 2010).

Among the most influential developments in the hydrological system of the Mekong are those related to hydropower. Planned new hydropower dams will have severe impacts on fisheries, by blocking critical migration routes and altering the river habitat in deep lakes, but also by trapping nutrient and sediment flows (Costanza et al. 2011; Baran and Guerin 2012; Ziv et al. 2012; Hijioka et al. 2014). Climate change is expected to amplify the impacts (Wyatt and Baird 2007; Grumbine et al. 2012; Orr et al. 2012; Räsänen et al. 2012; Ziv et al. 2012; Hijioka et al. 2014). In order to deal with the impacts of climate change, all riparian countries of the Mekong River Basin have national climate change 
adaptation plans. Effective transboundary adaptation requires further shared climate change forecasts and improved coordination, knowledge sharing, and mainstreaming of adaptation into transboundary, national, and local (development) planning. Many experts recommend a risk-based approach in climate change adaptation planning. Studies on climate change adaptation practices in the Lower Mekong River Basin countries show, however, that only $11 \%$ of on-the-ground efforts to adapt to climate change are driven by climate risks (Ding 2012; Neo 2012; Schaffer and Ding 2012; Hijioka 2014). Successful examples of on-the-ground adaptation efforts feature engagement of local stakeholders and participation throughout the process and robust assessments of adaptation gaps (Brown 2012; Khim and Phearanich 2012; Mondal 2012; Panyakul 2012; Roth and Grunbuhel 2012; Hijioka 2014). Effective transboundary adaptation planning across the members of the Mekong River Commission does not exist to date (Hijioka et al. 2014).

\section{Key findings from the special issue}

This section summarizes the key lessons learned from the various contributions to this special issue.

\subsection{Impacts of climate change and human interferences on water, nutrient, and sediment flows}

Both climate change and human intervention have an impact on the flows in the Mekong River Basin. Not only the water flow itself is of utmost importance to sustain livelihoods in the basin but also the nutrient and sediment flows are necessary for sustaining agriculture and avoiding coastal erosion in the Mekong Delta.

Many land use changes like deforestation, agricultural development and expansion of irrigation, conversion to reservoirs, and urbanization are ongoing at a rapid rate in the basin. Changes in land use affect the runoff, nutrient, and sediment loads in the drainage basin and can sometimes even have microclimatic impacts (Huong and Pathirana 2013). For example, deforestation can result in increased erosion and sediment loads in the runoff. The development of (hydropower) dams is at the same time trapping sediments and nutrients in the created reservoirs. Sedimentation rates in the reservoirs impact the storage capacity of the reservoirs and their functional life span.

Shrestha et al. (2018) evaluate (1) the impacts of climate change on reservoir sedimentation and (2) the impacts of climate change and reservoir development on sediment outflow in the Nam Ou River in Laos, a tributary of the Mekong River Basin. They analyzed scenarios for the development of one, three, or five reservoirs in series in the river and assessed sedimentation rates under no climate change and various climate change conditions. Shresta et al. find that climate change will increase sediment yields in the Nam Ou Basin and thus negatively impact the storage capacity of the reservoirs. However, the development of reservoirs will undo that change and reduce the sediment load of the outflow by 44 to $89 \%$. They conclude that dam development and their operation has a much larger impact on the downstream flows than climate change. Hence, they recommend further investigating appropriate reservoir management strategies both to expand the lifetime of reservoirs and to support the services that sediments provide downstream. 


\subsection{Climate change adaptation in urban centers}

Many cities around the world actively develop adaptation plans to be able to deal with the impacts of climate change. Although environmental sustainability is mentioned in the urban development plans of most cities in the Mekong River Basin, climate change adaptation is by and large not mainstreamed in these plans (Yuen and Kong 2009). Cities in the basin are impacted in various ways by climate change and urbanization can negatively aggregate these impacts. For example, groundwater exploration for the drinking water supply has led to land subsidence, causing problems in the urban drainage systems that are necessary to deal with stormwater runoff.

Three papers in this special issue focus on the city of Can Tho, located in the Vietnamese Mekong Delta. Radhakrishnan et al. (2018, this issue) use a methodology based on adaptation pathways to investigate the future changes needed to the flood risk management system in Can Tho. The authors show that the current planning process does not consider household coping capacities nor does it take future uncertainties adequately into account. They conclude that consideration of coping capacity of local households improves adaptation responses and leads to better adaptation outcomes.

In Part 1 of a two-part study, Pathirana, Radhakrishnan, Nguyen, and Zevenbergen (2018b) use Can Tho city to demonstrate a framework for integrating two types of adaptation. The authors argue that there is often competition and conflict in rapidly developing cities like Can Tho (the largest city in the Mekong Delta) between actions that address existing adaptation deficits (type I) and projected adaptation gaps (type II). They claim that synergistic action on type I and type II adaptation is essential for these cities to maintain liveability and build resilience to climate change in the face of growing urban populations. In Part II, the Pathirana et al. (2018a) propose a new approach called "Agile Urban Adaptation," involving twelve principles, that addresses adaptation deficits and adaptation gaps in one policy. They argue that the practical aspects of implementing aligned adaptation action can lead to improvements in liveability, sustainability, and resilience of the urban system.

These three works illustrate the importance of looking at climate adaptation in secondary cities in the global south (SCGS) from a broad-based angle that encompasses different drivers (global climate change vs urbanization), different approaches to adaptation (e.g., planned vs autonomous), different time-scales (short-, medium-, and long-term needs), and different actors (public vs private).

\subsection{Climate change adaptation in rural areas}

Rural communities can be dynamic and able to continuously adapt to a changing environment. However, rural communities in the Mekong River Basin often lack financial and institutional resources for formal adaptation planning. In this issue, we present papers that examine local climate change adaptations in the Chinese part of the Mekong River Basin (Gong et al. 2018) and in the Lower Mekong River Basin (Gustafson et al. 2018).

In analyzing farmer's adaptation strategies in China's Lan Can River, Gong et al. identify two types of capital involved in technology adoption: bridging capital (e.g., access to financial capital) and bonding social capital (e.g., access to community). They find that while adaptation measures have been widely taken, non-infrastructure-based measures are more prevalent than infrastructure-based measures. Households tend to have strong social capital but weak bridging capital. Gong et al. conclude that government efforts to improve the 
adaptive capacity of rural communities should include accessibility to formal financial institutions to improve bridging capital, capacity development (e.g., training in disaster management), and access to improved extension services for technology adoption.

In a study on the drivers of adaptation planning in the Lower Mekong River Basin, Gustafsen et al. find that the development adaptation plans tend to be either predominantly science-led or predominantly community-led. Their results indicate that merging scientific data and community perspectives can fill knowledge gaps from both sides and lead to a more comprehensive understanding of vulnerability for use in adaptation planning. Community perspectives can effectively contribute to short-term actions, while science helps ensure the adaptation trajectory addresses the longer-term range in projection outlooks, maintaining resilience, flexibility, and a vision that captures the needs of future generations. Both scientific and community perspectives are crucial to come to developing appropriate adaptation measures.

These two works show the relevance of further transdisciplinary work and the necessity of taking local knowledge, adaptation practices, and capacity (capital) seriously in developing climate change adaptation plans for rural communities.

\subsection{Transboundary river management}

The Mekong River is a transboundary waterway, but the Mekong River Basin also includes many transboundary sub-basins that influence the flow of water, sediments, and nutrients in the main river. The Mekong River Commission supports transboundary management of the Lower Mekong River, but its mandate is limited to only the main stem. The developments and management of transboundary tributary rivers are beyond the influence of the commission and happen via bilateral agreements. This has created a situation which makes it virtually impossible to effectively manage the main stem of the Mekong River (Sithirith et al. 2016).

With twelve reservoirs built in Vietnam and three reservoirs planned in Cambodia, the transboundary Sesan and Srepok river basins are considered as "hot-spot" areas for reservoir development in the Lower Mekong Basin. Ngo et al. (2018) examine the impacts of the projected reservoirs and related (hydropower) operation scenarios on downstream flow regimes in the context of climate change and downstream flow. Climate change is expected to induce changes in the flow regime, but similar to the findings of Shrestha et al. (2018), these changes are small in comparison to those caused by the reservoir operations. Various reservoir operation scenarios could both counterbalance and reinforce the climate change impacts. During the dry season, they expect a counterbalancing effect and in the rainy months, reservoirs may exacerbate the increased flow due to climate change. The results of this study provide information for reservoir managers to reduce negative downstream trade-offs of reservoir operation.

The results suggest that dam operators need to adapt their management and operations to account for climate change and for bilateral agreements on (minimum and maximum) flows crossing international borders. Reservoirs are often promoted to be buffers and to increase water security in times of climate change. Nevertheless, at the same time, dam operations can cause downstream flash floods to flush out (increased) sediment loads from the reservoirs or to avoid overloads of water in the reservoir (which can negatively impact downstream communities). In rivers with cascading dams, this requires communication and coordination between the various dam operators. 


\section{Conclusions}

The Mekong River Basin region is vulnerable to direct impacts of climate change, but mostly due to the limited capacities to adapt to climate change. The region is rapidly developing, in terms of infrastructure in the water system and the socioeconomic situation of the communities. The papers in this special issue show that climate change, development, and human interventions will dramatically influence the flows in the Mekong River Basin. Human interventions have the potential to reduce the negative impacts of climate change, but climate change can also increase the negative impacts of human interventions. Climate change impacts will affect different communities within the Mekong River Basin in different ways, and in turn, different communities in the basin will have different impacts on the future river flows. Better understanding of the complex interrelations between climate change, technological interventions, land use change, water use change, and socioeconomic developments in the upstream and downstream riparian countries is needed to better support climate change adaptation strategies. The papers presented in this issue offer insights from a wide variety of scientific disciplines, geographical focus, and adaptation themes.

We are convinced that inter-, multi-, and transdisciplinary research and further sharing of knowledge between scientific disciplines and relevant decision makers (international, national, and local) are necessary to move forward in better understanding the complexities of adaptation and in actually supporting climate change adaptation in urban and rural communities in the Mekong River Basin.

Acknowledgements We thank the editors of Climatic Change for supporting the development of this special issue. We are grateful for their insights and contributions to improve this work. We thank all authors and peer reviewers for their contributions.

\section{References}

Allison EH, Perry AL, Badjeck MC, Neil Adger W, Brown K, Conway D, Andrew NL (2009) Vulnerability of national economies to the impacts of climate change on fisheries. Fish Fish 10(2):173-196

Baran, E., \& Guerin, E. (2012). Dams, changes in sediment load and impact on fish resources in the Mekong: approach and way forward. Report for the Project "A climate resilient mekong: maintaining the flows that nourish life" led by the Natural Heritage Institute. World Fish Center, Phnom Penh, Cambodia

Brooks, N., \& Adger, N. W. (2003). Country level risk measures of climate-related natural disasters and implications for adaptation to climate change

Brown, S. M. (2012). The conservation and development of the Kien Giang Biosphere Reserve: adaptation to climate change. Asian Journal of Environment and Disaster Management, 4(4)

Costanza, R., Kubiszewski, I., Paquet, P., King, J., Halimi, S., Sanguanngoi, H., Intralawan, A. (2011). Planning approaches for water resources development in the Lower Mekong Basin

Ding L (2012) Application of an operational framework for identifying successful adaptation projects in the Lower Mekong Basin. Asian J Environ Dis Manag 4(4)

Dun O (2011) Migration and displacement triggered by floods in the Mekong Delta. Int Migr 49(s1)

Eastham, J., Mpelasoka, F., Mainuddin, M., Ticehurst, C., Dyce, P., Hodgson, G., Kirby, M. (2008). Mekong river basin water resources assessment: impacts of climate change. Clayton, South Victoria, Australia. Retrieved from: http://citeseerx.ist.psu.edu/viewdoc/download?doi=10.1.1.457.9113\&rep= rep1\&type=pdf. Accessed 29 Dec 2017

Garschagen, M., \& Kraas, F. (2011). Urban climate change adaptation in the context of transformation: lessons from Vietnam. In Resilient cities (pp. 131-139): Springer 
Gong, Y., Li, H., Parks, M., Pang, J., \& de Fraiture, C. (2018). The role of social capital for farmers' climate change adaptation in Lancang River basin in China. Clim Chang, 15pp

Grumbine RE, Dore J, Xu J (2012) Mekong hydropower: drivers of change and governance challenges. Front Ecol Environ 10(2):91-98

Gustafson S, Cadena AJ, Ngo CC, Kawash A, Saenghkaew I, Hartman P (2018) Merging science into community adaptation planning processes: a cross-site comparison of four distinct areas of the Lower Mekong Basin. Clim Chang:16pp

Halls, A.S. (2009). Addressing fisheries in the Climate Change and Adaptation Initiative. Catch and Culture: Fisheries Research and Development in the Mekong Region, 15(1), 12-16.

Hijioka, Y., E. Lin, J.J. Pereira, R.T. Corlett, X. Cui, G.E. Insarov, R.D. Lasco, E. Lindgren, and A. Surjan (2014). Asia In: Climate change 2014: impacts, adaptation, and vulnerability. Part B: regional aspects. Contribution of Working Group II to the Fifth Assessment Report of the Intergovernmental Panel on Climate Change [Barros, V.R., C.B. Field, D.J. Dokken, M.D. Mastrandrea, K.J. Mach, T.E. Bilir, M. Chatterjee, K.L. Ebi, Y.O. Estrada, R.C. Genova, B. Girma, E.S. Kissel, A.N. Levy, S. MacCracken, P.R. Mastrandrea, and L.L. White (eds.)]. Cambridge University Press, Cambridge, United Kingdom and New York, NY, USA, pp. 1327-1370

Huong HTL, Pathirana A (2013) Urbanization and climate change impacts on future urban flooding in Can Tho city, Vietnam. Hydrol Earth Syst Sci 17:379-394. https://doi.org/10.5194/hess-17-379-2013

ICEM (2009), Climate change adaptation in the Lower Mekong Basin countries REGIONAL SYNTHESIS REPORT prepared by ICEM - International Centre for Environmental Management, 28 March, 2009

Keskinen M, Chinvanno S, Kummu M, Nuorteva P, Snidvongs A, Varis O, Västilä K (2010) Climate change and water resources in the Lower Mekong River Basin: putting adaptation into the context. J Water Clim Chang 1(2):103-117

Khim, L., \& Phearanich, H. (2012). Climate resilience in rural Cambodia: adaptation mainstreaming, water resource management and agricultural practice. Asian Journal of Environment and Disaster Management, 4(4)

Merme V, Ahlers R, Gupta J (2013) Private equity, public affair: hydropower financing in the Mekong Basin. Glob Environ Chang 24:20-29

Mondal, P. (2012). Baseline assessments, vulnerability analysis and finding sustainable livelihood options: designing a climate change adaptation project in Ben Tre province, Vietnam. Asian Journal of Environment and Disaster Management, 4(4)

MRC (2009). Adaptation to climate change in the countries of the Lower Mekong Basin. MRC Technical Paper, 24, 5-24. MRC. (2010a). Impacts of climate change and development on Mekong flow regimes First assessment - 2009, MRC Technical Paper No.29. MRC, Vientiane, Laos

MRC (2010). State of the basin report 2010. MRC: Vientiane, Laos

MRC (2016). Integrated water resources management-based basin development strategy 2016-2020 for the lower Mekong Basin. MRC: Vientiane, Laos

MRC (Mekong River Commission) (2005). Overview of the hydrology of the Mekong Basin. MRC, Vientiane, Laos

Murphy T, Irvine K, Sampson M (2013) The stress of climate change on water management in Cambodia with a focus on rice production. Clim Dev 5(1):77-92

Neo, L. (2012). Governance issues in climate change adaptation in the Lower Mekong Basin: perspectives from practitioners. Asian Journal of Environment and Disaster Management, 4(4)

Ngo, L. A., Masih, I., Jiang, Y., \& Douven, W. (2018). Impact of reservoir operation and climate change on the hydrological regime of the Sesan and Srepok Rivers in the Lower Mekong Basin. Clim Chang, 13pp

Nuorteva P, Keskinen M, Varis O (2010) Water, livelihoods and climate change adaptation in the Tonle Sap Lake area, Cambodia: learning from the past to understand the future. J Water Clim Chang 1(1):87-101

Orr S, Pittock J, Chapagain A, Dumaresq D (2012) Dams on the Mekong River: lost fish protein and the implications for land and water resources. Glob Environ Chang 22(4):925-932

Panyakul, V. R. (2012). Climate change adaptation through agro-social enterprise: Green Net's experiences in Thailand. Asian Journal of Environment and Disaster Management, 4(4)

Pathirana, A., Radhakrishnan, M., Ashley, R., Quan, N. H., \& Zevenbergen, C. (2018a). Managing urban water systems with significant adaptation deficits - unified framework for secondary cities: part II — the practice. Clim Chang, 18pp

Pathirana A, Radhakrishnan M, Nguyen HQ, Zevenbergen C (2018b) Managing urban water systems with significant adaptation deficits — unified framework for secondary cities: part I — conceptual framework. Clim Chang:14pp. https://doi.org/10.1007/s10584-017-1953-9

Radhakrishnan, M., Nguyen, H. Q., Gersonius, B., Pathirana, A., Vinh, K. Q., Ashley, R. M., \& Zevenbergen, C. (2018). Coping capacities for improving adaptation pathways for flood protection in Can Tho, Vietnam. Climatic Change, 13pp 
Räsänen TA, Koponen J, Lauri H, Kummu M (2012) Downstream hydrological impacts of hydropower development in the Upper Mekong Basin. Water Resour Manag 26(12):3495-3513

Roth, C. H., \& Grünbühel, C. M. (2012). Developing multi-scale adaptation strategies: a case study for farming communities in Cambodia and Laos. Asian Journal of Environment and Disaster Management, 4(4)

Schaffer, A., \& Ding, L. (2012). Strengthening climate adaptation in the Lower Mekong River basin through a regional adaptation action network. Asian Journal of Environment and Disaster Management, 4(4)

Shrestha, B., Maskey, S., Babel, M. S., van Griensven, A., \& Uhlenbrook, S. (2018). Sediment related impacts of climate change and reservoir development in the Lower Mekong River Basin: a case study of the Nam Ou Basin, Lao PDR, Climatic Change, 15pp

Sithirith M, Evers J, Gupta J (2016) Damming the Mekong tributaries: water security and the MRC 1995 Agreement. Water Policy. https://doi.org/10.2166/wp.2016.003

Smit B, Burton I, Klein RJ, Wandel J (2000) An anatomy of adaptation to climate change and variability. Clim Chang 45(1):223-251

TTK \& SASRC (Water and Development Research Group Helsinki University of Technology (TKK), \& Southeast Asia START Regional Center (SASRC) (2008). Water and climate change in the Lower Mekong Basin: diagnosis \& recommendations for adaptation. Retrieved from Helsinki: https://ppcrcambodia.files.wordpress.com/2012/11/water-and-climate-change-in-the-lmb-diagnosisrecommendations-for-adaptation.pdf. Accessed 28 Dec 2017

UNEP (2016). The adaptation finance gap report 2016. United Nations Environment Programme (UNEP), Nairobi, Kenya. Retrieved from: http://web.unep.org/adaptationgapreport/sites/unep.org. adaptationgapreport/files/documents/agr2016.pdf Accessed 29 Jun 2018

Warner K (2010) Global environmental change and migration: governance challenges. Glob Environ Chang 20(3):402-413

Watson, R. T., \& Albritton, D. L. (2001). Climate change 2001: synthesis report: third assessment report of the Intergovernmental Panel on Climate Change. Cambridge University Press

Wyatt AB, Baird IG (2007) Transboundary impact assessment in the Sesan River Basin: the case of the Yali Falls Dam. Water Resour Dev 23(3):427-442

Yuen, B., \& Kong, L. (2009). Climate change and urban planning in Southeast Asia. SAPIENS. Surveys and Perspectives Integrating Environment and Society, 2(3)

Ziv G, Baran E, Nam S, Rodríguez-Iturbe I, Levin SA (2012) Trading-off fish biodiversity, food security, and hydropower in the Mekong River Basin. Proc Natl Acad Sci 109(15):5609-5614 